\title{
Effects of Perturbation Training on Balance, Walking, and Lumbar Stabilization in Patients with Multiple Sclerosis: A Pilot Study
}

\section{Multipl Skleroz Hastalarında Pertürbasyon Eğitiminin Denge, Yürüyüş ve Lumbar Stabilizasyon Üzerine Etkisi: Pilot Çalışma}

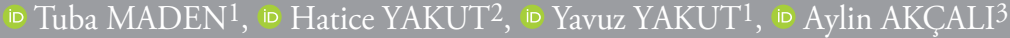

${ }^{1}$ Hasan Kalyoncu University Faculty of Health Sciences, Department of Pyhsioteraphy and Rehabillitation, Gaziantep, Turkey

2Süleyman Demirel University Faculty of Health Sciences, Department of Pyhsioteraphy and Rehabillitation, Isparta, Turkey

${ }^{3}$ Gaziantep University Faculty of Medicine, Department of Neurology, Gaziantep, Turkey

\section{ABSTRACT}

Objective: To investigate the effect of perturbation training (PT) on balance, walking, and lumbar stabilization in patients with multiple sclerosis.

Methods: Ten patients were given manual PT twice a week for 6 weeks. Romberg (RT), Sharpened Romberg (SR), and single leg stance test (SLST) were performed for static balance. Dynamic balance was assessed with functional reach test (FRT), lateral reach test [dominant (LRT-D) and non-dominant (LFR-ND)], and four square step test (FSST). The Falls Efficacy Scale International (FES-I) was used to evaluate the fear of falling. Timed up and go (TUG) test and pressure biofeedback stabilization were used to assess the functional mobility and lumbar stabilization.

Results: The results of SR and SLST were significantly increased after the treatment $(\mathrm{p}<0.05)$. However, the RT duration had no differences between pre and post-treatments $(p>0.05)$. Significant differences were found in the values of FRT and LRT-ND. The results of LRT-D and FSST were not changed with the treatment. The fear of falling decreased after the treatment but was not statistically significant $(p>0.05)$. After the treatment, the TUG duration improved in participants $(\mathrm{p}=0.01)$. No difference was found in the PBS duration between the pre and post-treatment $(\mathrm{p}>0.05)$.

\section{ÖZ}

Amaç: Multipl skleroz hastalarında pertürbasyon eğitiminin (PE) denge, yürüme ve lumbal stabilizasyon üzerine etkisini araştırmak.

Yöntemler: On hastaya 6 hafta boyunca haftada iki kez manuel PE verildi. Statik denge için Romberg Test (RT), Keskinleştirilmiş Romberg (KR), Tek Bacak Duruş Testi (TBDT) yapıldı. Dinamik denge Fonksiyonel Uzanma Testi (FUT)'yle, Lateral Uzanma Testi (dominant, non-dominant; LUT-D, LUT-ND)'yle ve Dört Kare Adım Testi (DKAT)'yle değerlendirildi. Düşme korkusunu değerlendirmek için Düşme Etkinliği Skalası (DES) kullanıldı. Fonksiyonel mobilite ve lumbal stabilizasyonu değerlendirmek için sırasıyla Zamanlı Kalk ve Yürü (ZKY) testi, Basınçlı Biofeedback Stabilizer (BBS) kullanıldı.

Bulgular: SR ve SLST sonuçları tedaviden sonra anlamlı olarak arttı $(\mathrm{p}<0,05)$. Ancak RT süresi için tedavi öncesi ve sonrası arasında fark yoktu $(p>0,05)$. FUT ve LUT-ND değerleri arasında önemli fark vardı. Tedavi ile LUT-D ve DKAT sonuçları değişmedi. Tedavi sonrasında bireylerin düşme korkusu azalsa da, istatistiksel analize yansımadı $(p>0,05)$. Tedaviden sonra ZKY süresinde iyileşmeler kaydedildi $(\mathrm{p}=0,01)$. Tedavi öncesi ve sonrası arasında BBS süresi bakımından fark yoktu ( $\mathrm{p}>0,05)$.

Sonuç: Bu çalışma, klinikte bilgisayarlı sistemler olmadan manuel PE’nin statik ve dinamik dengeyi, yürüyüşü, düşme korkusunu
Address for Correspondence: Tuba MADEN, Hasan Kalyoncu University Faculty of Health Sciences, Department of Pyhsioteraphy and Rehabillitation, Gaziantep, Turkey E-mail: tuba.kaplan@hku.edu.tr ORCID ID: orcid.org/0000-0001-8713-0825

Cite this article as: Maden T, Yakut H, Yakut Y, Akçalı A. Effects of Perturbation Training on Balance, Walking, and Lumbar Stabilization in Patients with Multiple Sclerosis: A Pilot Study.

Bezmialem Science 2022;10(1):10-16

Bezmiâlem Science published by Galenos Publishing House. 
Conclusion: This study revealed that manual PT without computerized systems in the clinic may improve static and dynamic balance, walking, and fear of falling. Additionally, the effect of PT on lumbar stabilization in MS was not determined in our study. Major conclusions were limited by the small sample size; however, the observed results may contribute to designing future trials.

Keywords: Gait, multiple sclerosis, postural balance, rehabilitation iyileştirebileceğini göstermiştir. Ayrıca çalışmamızda PE'nin multipl sklerozda lumbal stabilizasyon üzerine etkisi saptanmadı. Önemli sonuçlarımız küçük örneklem büyüklüğü ile sınırlıydı; ancak, gözlemlenen sonuçlar gelecekteki çalışmaların tasarlanmasına katkıda bulunabilir.

Anahtar Sözcükler: Yürüyüş, multipl skleroz, postural denge, rehabilitasyon

\section{Introduction}

Multiple sclerosis (MS) is a chronic inflammatory autoimmune neurological disease that is characterized by myelin destruction in the central nervous system (CNS), grey matter, and axonal loss (1). The damage within the CNS slows the nerve conduction and decreases motor activation that coincides with impaired motor performance (2). Altered balance, walking dysfunction, muscle weakness, reduced core stabilization, and fatigue are symptoms of impaired motor performance $(3,4)$. Especially, core muscle strength is necessary for skilled movement and function (5). Physiotherapy and rehabilitation training includes strength and stretch and balance and coordination exercises for patients with MS in the baseline. Recently, task-oriented training and wholebody vibration have proved benefits in patients with MS (6). Perturbation training (PT) has been incorporated into balance training (7). Anticipatory (APAs) and compensatory postural adjustments (CPAs) are the two main postural mechanisms used by the CNS to maintain and restore balance during perturbations (8). APAs are responsible for postural muscle activation in a feed-forward manner before perturbations (9). Predicted or small perturbations can only be counteracted with APAs (10). Unexpected or large perturbations can be counteracted with CPAs (10). Perturbations develop an automatic postural response, which is known as the primary component of postural control (11). PT is aimed to improve reactive balance control, step quality, and reduce the risk of falling $(12,13)$. The inefficient APAs cause fear of falling, slow mobility, and poor balance in older adults (14). The muscle activity during APAs was smaller and delayed than healthy persons, even in the early phase of MS (15). Additionally, few studies investigated the effect of PT on lumbar stabilization (16), which revealed that external perturbations increased intramuscular electromyography signals, especially the transversus abdominis (17). Unexpected perturbation to the transversus abdominis plays a key role in lumbar stabilization compared to other trunk muscles (16).

The effects of PT are shown in different areas in different diseases, in the elderly, e.g., stroke, Parkinson's disease, and anterior cruciate ligament ruptures $(12,18-20)$. PT stimulated the neuromotor system, improved sensorimotor skills, and prevented falling (21). Lateral perturbations were improved in the magnitude of CPAs for patients with Parkinson's disease to develop balance and reduce falls (14). Perturbations provide information on the strategies of adjustments, but the effects of PT were not clearly understood in patients with MS (22). The effects of perturbations on the fear of falling are still unknown.
Thus, investigating the effect of PT on MS is necessary. This study aimed to investigate the effect of PT on balance, walking, and lumbar stabilization.

\section{Method}

This is a pilot study that was approved by Hasan Kalyoncu University, Clinical Researches Ethics Committee in June 2017 (number: 2017/255). Informed consent was obtained from all participants.

\section{Participants}

This study included 10 patients with MS between July and December 2017 (Figure 1). The inclusion criteria were (1) Mc Donald's MS diagnosis following the 2010 criteria, (2) ages 18-45 years, (3) and Expanded Disability Status Scale (EDSS) score of 3-5.5. The exclusion criteria were (1) 3 or higher scores in spasticity according to Modified Ashworth Scale, (2) psychological, orthopedic, and other neurological disorders, and (3) attacks in the last 3 months.

\section{Procedure}

All patients attained a physiotherapy program. Perturbations were manually applied, and precautionary measures were taken to avoid the risk of injuries. PT was carried out in different positions that included standing, kneeling, and sitting. Manual perturbations in each position were applied 10-12 times, and individuals were allowed to rest for $10 \mathrm{~s}$ between each position at a sitting position. Perturbations were applied for $5 \mathrm{~min}$, along with $10 \mathrm{~s}$ break between two successive sets. Perturbations were performed in both right and left sideways, backward and forward in each of positions, and at the pelvis and shoulders in different directions. The duration of one session was $45 \mathrm{~min}$. Treatment was given twice a week for 6 weeks (23). Participants did not receive any other treatment or physiotherapy application. The treatment and assessment tests were carried out by the same physiotherapist.

\section{Measurements}

\section{Statics Balance Tests}

Romberg (RT), Sharpened Romberg (SR), and single leg stance test (SLST) were performed and their duration was recorded. RT was performed on patients with eyes closed and feet together. The test was terminated when the participant held it in one place, oscillations began or were likely to fall (24). RT maximum duration was $120 \mathrm{~s}$. SR was performed on a straight line with one 


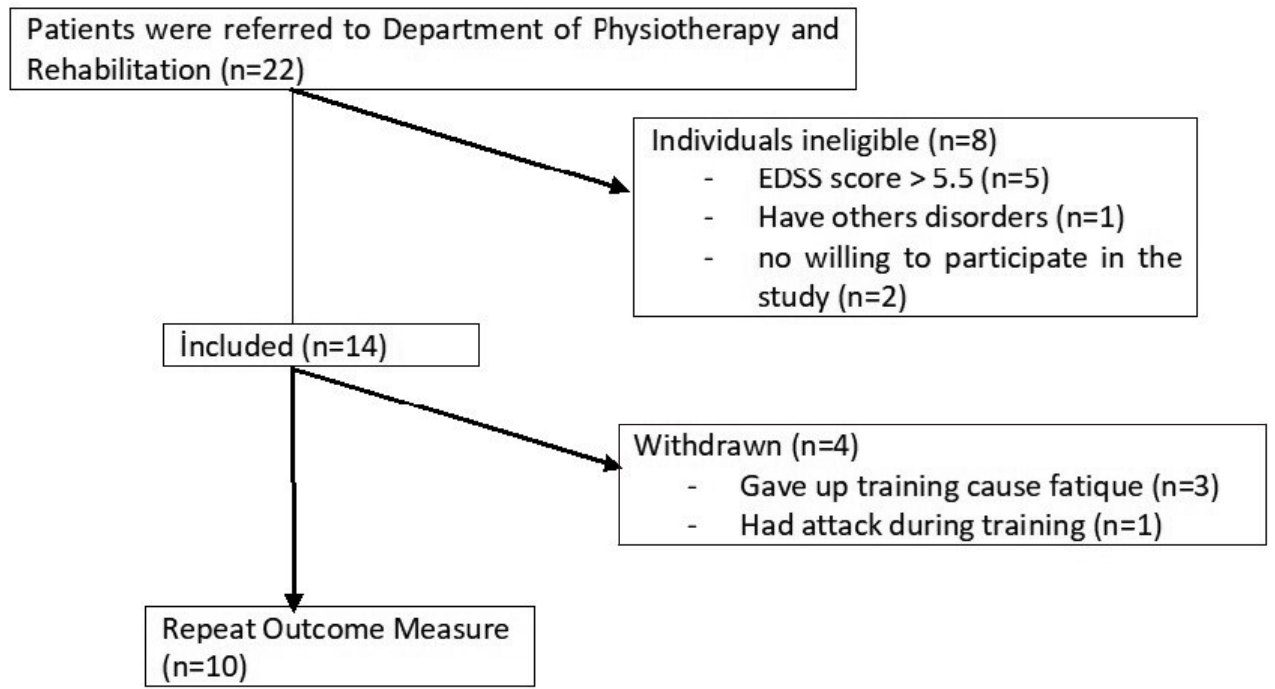

Figure 1. Follow-up diagram

leg behind the other leg, eyes open, and leaving the arms sagging, without impairing the balance. Duration stop criteria were defined as the time that took a participant to dislocate the foot, reach the maximal duration of $30 \mathrm{~s}$, and contact the observer to avoid falling (25). An SLST was measured in a standing position with dangling arms. The duration was stopped when the participant re-positioned his/her supportive foot, touched their feet to the ground, sought support from the observer, and reached the maximum duration of $30 \mathrm{~s}$ (16).

\section{Dynamic Balance Tests}

Dynamic balance was assessed with functional reach test (FRT), lateral reach test (LRT), and four square step test (FSST). FRT was performed by reaching forward and lateral without taking a step. The level of the metacarpal bone was marked in the start position and final position. The difference between these levels was measured (26). LRT was performed with both sides that included dominant and non-dominant sides (27). LRT is a reliable and valid measure for lateral stability limits and mediolateral balance in the MS population (28). FSST measured dynamic balance and included all directions, e.g., backward, forward, right, and left (29). The time of the test was recorded while the participant rapidly stepped in clockwise and counterclockwise rotations (30).

\section{Walking}

A timed up and go (TUG) test was used for functional mobility that was related to falling risk. Individuals in TUG were asked to stand from the sitting position, walk $3 \mathrm{~m}$, turn back, and sit back on the chair again (31).

\section{Lumbar Stabilization Test}

Core muscle performances were assessed with a Pressure Biofeedback Stabilizer (PBS) (Chattanooga, Australian) (32). Individuals were positioned to stand with their comfortable foot distance and their back resting on the wall. The stabilizer's pressure cell was placed under L3-4 spinous processes and was inflated to a baseline pressure of $40 \mathrm{mmHg}$. All individuals were asked to have a stable baseline pressure. The duration without moving their spine or pelvis was recorded. Three trials were performed and the best scores were recorded (5).

\section{Fear of Falling}

Falls Efficacy Scale International (FES-I) was used to evaluate the level of concern related to falls during 16 activities of daily living. This questionnaire quantifies the level of concern about falling while performing each activity on a 4-point scale ( $1=$ not at all; $2=$ somewhat; $3=$ quite a lot; and $4=$ very). The total score is between 16 and 64, in which a higher score indicates more concern about falling (33).

\section{Statistical Analysis}

Statistical Package for the Social Sciences version 22.0 software was used for statistical analyses. $G^{*}$ power application was used to calculate the necessary minimum sample size. The sample size was calculated to be 19 subjects with 5\% type 1 and $10 \%$ type 2 error limits before and after treatment to provide $90 \%$ working power, gain 0.80 of effect size, and 95\% confidence interval. The frequency in percent $(\%)$ and mean \pm standard deviation $(\mathrm{X} \pm \mathrm{SD})$ of necessary variables were calculated for the descriptive analyses. Normality of distribution was tested with the Skewness-Kurtosis and histogram graphic. Paired samples t-test was used for the comparison of two measurements; pre and post-treatment. Differences were assumed significant at $\mathrm{p}$-values of $<0.05$.

\section{Results}

The demographic characteristics of participants are shown in Table 1. All participants had a Relapsing-Remitting type of MS. The diagnosis period of participants varied between 2 and 15 years. The average EDSS score was 1.87. All participants were right-handed. Two participants have no history of falling, 
whereas three participants fell one time or two times in the last year and five participants have $>2$ histories of falls in the last year.

SR and SLST, which were used to test the static balance, significantly increased after the treatment $(\mathrm{p}<0.05)$ (Table 2$)$; however, RT had no differences between the pre and posttreatment periods $(\mathrm{p}>0.05)$ (Table 2). Significant differences were found in FRT and LRT-ND (Table 2). FSST dynamic balance test was not changed with the treatment period $(p>0.05)$ (Table 2). The fear of falling decreased after the treatment, without statistically significant analysis $(p>0.05)$ (Table 2). After the treatment, TUG improved in participants $(\mathrm{p}=0.01)$ (Table 2 ). However, no differences were found in PBS between the preand post-treatment periods ( $\mathrm{p}>0.05$ ) (Table 2 ).

\section{Discussion}

This study aimed to investigate the effect of PT on balance, walking, and lumbar stabilization in patients with MS. A significant effect of PT was recorded on balance and walking. However, the improvement in fear of falling was observed to be clinically but not statistically significant. Investigating the effect of PT on balance, walking, lumbar stabilization, and fear of falling is effective in long-term MS.

Table 1. The demographics characteristics in participants

\begin{tabular}{l|l|}
\hline Characteristics & Mean \pm SD (min-max) \\
\hline $\begin{array}{l}\text { Age (year) } \\
\text { Years since diagnosis }\end{array}$ & $37.12 \pm 7.21(26-45)$ \\
\hline $\begin{array}{l}\text { Expanded disability status scale (scores) } \\
\text { Gender }\end{array}$ & $1.00 \pm 4.27(2-15)$ \\
\hline $\begin{array}{l}\text { Female } \\
\text { Male }\end{array}$ & 8 \\
\hline $\begin{array}{l}\text { Fall history } \\
\text { No }\end{array}$ & 2 \\
\hline $1-2$ in the last year & 2 \\
$>2$ in the last year & 3 \\
\hline
\end{tabular}

Perturbations are known to improve CPAs and APAs and positively affect balance and walking in the elderly $(19,34)$. Both gait and fear of falling are affected by gender. Functional walking categories revealed that walking performance changed according to age and gender in patients with MS (35). Therefore, the effects of PT according to age and gender should be compared in a larger sample. The range of age and the number of participants were limited in our study. As this is a pilot study, the effects of age or gender were not determined. Further studies might focus on investigating the response of $\mathrm{PT}$ according to age and gender.

Studies investigated the perturbation direction in the literature. Morrison et al. (36) showed that persons with MS exhibited greater sway in the mediolateral direction compared to the anteroposterior direction. The comparison of the elderly revealed that mediolateral sway was greater in MS, which increased the falling risk and affected the activity in daily life (36). Cortesi et al. (37) determined that their treatment improved not only the mediolateral balance but also the anteroposterior balance. Additionally, Salc1 et al. (11) demonstrated that proprioceptive neuromuscular facilitation techniques should be applied for motor strategy training, and balance, and especially posterior perturbations should be preferred. This study performed perturbations in all directions. The mediolateral balance was thought to be more difficult to develop since it was more affected according to the FSST and LRT results. A more intensive treatment program may be required to improve the mediolateral balance.Perturbations disturb individual stability and supply feedback postural control, thus they improve the balance (38). However, perturbations should be sufficient to improve reactive balance control (39). The amount of perturbations is unclear. A study showed that it should be 24 perturbations at one session and another argued that it should include approximately 80 perturbations over four sessions $(40,41)$. Some studies determined approximately 700-1,150 perturbation overall training $(42,43)$. This study performed approximately 75 perturbations in one session that includes three positions (i.e., sitting, stand, and tandem positions) 1012 times in each position for two successive sets. The number of perturbations was thought to be sufficient to improve the

Table 2. Pre-post outcome measures: balance, walking, lumbar stabilization, and fear of falling

\begin{tabular}{|c|c|c|c|}
\hline Measurements & Pre-treatment & Post-treatment & p-value \\
\hline Romberg Test (sec) & $78.21 \pm 57.78$ & $98.54 \pm 41.74$ & 0.285 \\
\hline Sharpened Romberg Test (sec) & $9.28 \pm 11.5$ & $46.65 \pm 34.91$ & $0.018^{*}$ \\
\hline Functional Reach Test $(\mathrm{cm})$ & $25.58 \pm 5.43$ & $33.18 \pm 4.44$ & $0.011^{*}$ \\
\hline Lateral Reach Test-D (cm) & $20.56 \pm 8.59$ & $25.29 \pm 6.79$ & 0.098 \\
\hline Timed Up and Go test (sec) & $9.23 \pm 1.92$ & $7.41 \pm 1.04$ & 0.01 * \\
\hline Pressure Biofeedback Stabilizer (sec) & $26.67 \pm 13.47$ & $33.02 \pm 16.92$ & 0.45 \\
\hline Fear Efficacy Scale International (Score) & $40.63 \pm 24.04$ & $25.00 \pm 16.89$ & 0.06 \\
\hline
\end{tabular}


balance and gait of MS. More studies are needed to determine the exact amount in patients with MS.

van Duijnhoven et al. (13) determined that perturbations improved the quality of stepping in patients with chronic stroke but not the speed of gait. Another study applied PT on the treadmill and revealed that PT improved the dynamic balance and walking in the elderly (34). Further, another study investigated the effect of PT on gait in Parkinson's disease using the 6-meter walk test and TUG (44). Compared with the control group, PT was determined to improve the performance in TUG but remained unchanged in the 6-meter walk test duration (44). Our primary findings indicate that PT might support improvements in walking performance in patients with MS. Our study findings were similar to the literature. To our knowledge, performing PT in MS is the original feature of our study. However, our study investigated only the speed of walking in MS. Other studies in literature investigated the gait in detail. Aruin et al. (22) determined that perturbations improved CPAs and APAs and changed gait initiation in MS. Tajali et al. (14) showed that external perturbations change in core muscle activity during walking in MS. Thus, the effect of PT on walking can be investigated in detail like electromyography activity.

After perturbations, improved balance and accurate stepping are essential strategies to prevent falling and reduce the fear of falling (34). PT focuses on response to improve reactive balance and reduce the risk of falling (12). PT was performed in 10 sessions for patients with chronic stroke in a study and showed increased activity-specific confidence, but no statistically significant differences (13). However, the increased activity-specific confidence after 6 weeks was greater than the post-treatment. Thus, the effect of PT on the fear of falling became apparent in the follow-up period. Our study revealed a decreased fear of falling with PT training following the literature. However, the effect of treatment is thought to be better in the long term. Fear is known as a psychogenic composite parameter and fear is affected by psychosocial factors. Thus, the fear of falling is thought to be follow-up as long term in patients.

Freeman et al. (16) emphasized the effect of unexpected perturbations on core stabilization that is directly controlled by CNS and PT supplied feedback and proprioception for deficits in neuromuscular control of stabilization; therefore, PT improved lumbar stabilization (45). Vera-Garcia et al. (46) showed that trunk perturbations increased preactivation of core muscles and trunk stability and reduced lumbar displacement. Another study proved that high-intensity perturbations increased neuromuscular activity (47). However, no significant differences were found in PBS. Future studies are necessary to investigate the effect of PT on lumbar stabilization that includes more intense training. The effect of PT on patients with MS remains unclear.

\section{Study Limitations}

This study had several limitations, such as the small sample size that has no control group. Future studies that investigate the effect of PT in the long term are needed to understand the effect of PT on MS.

\section{Conclusion}

This study revealed that PT may improve static and dynamic balance, walking, and fear of falling. The balance was insufficiently developed in the mediolateral direction with the PT. Additionally, the effect of PT on lumbar stabilization in MS was not determined in our study. Major conclusions were limited by the small sample size; however, the observed results may contribute to designing future trials.

\section{Ethics}

Ethics Committee Approval: This is a pilot study that was approved by Hasan Kalyoncu University, Clinical Researches Ethics Committee in June 2017 (number: 2017/255).

Informed Consent: Informed consent was obtained from all participants.

Peer-review: Externally peer reviewed.

\section{Authorship Contributions}

Surgical and Medical Practices: T.M., H.Y., Y.Y., A.A., Concept: T.M., H.Y., Design: T.M., H.Y., Data Collection or Processing: T.M., A.A., Analysis or Interpretation: T.M., H.Y., Y.Y., A.A., Literature Search: T.M., H.Y., Writing: T.M., H.Y., Y.Y., A.A.

Conflict of Interest: No conflict of interest was declared by the authors.

Financial Disclosure: The authors declared that this study received no financial support.

\section{References}

1. Campbell E, Coulter EH, Mattison PG, Miller L, McFadyen A, Paul L. Physiotherapy rehabilitation for people with progressive multiple sclerosis: a systematic review. Arch Phys Med Rehabil 2016;97:14151.e3.

2. Learmonth YC, Ensari I, Motl RW. Physiotherapy and walking outcomes in adults with multiple sclerosis: systematic review and meta-analysis. Phys Ther Rev 2016;21:160-72.

3. LaRocca NG. Impact of walking impairment in multiple sclerosis: perspectives of patients and care partners. Patient 2011;4:189-201.

4. Lanzetta D CD, Pellegatta D and Cardini R. Trunk control in unstable sitting posture during functional activities in healthy subjects and patients with multiple sclerosis. Arch Phys Med Rehabil 2004;85:279-83.

5. Fry DK, Huang M, Rodda BJ. Core muscle strength and endurance measures in ambulatory persons with multiple sclerosis: validity and reliability. Int J Rehabil Res 2015;38:206-12.

6. Amatya B, Khan F, Galea M. Rehabilitation for people with multiple sclerosis: an overview of Cochrane Reviews. Cochrane Database Syst Rev 2019;1:CD012732.

7. Mansfield A, Aqui A, Centen A, Danells CJ, DePaul VG, Knorr S, et al. Perturbation training to promote safe independent mobility poststroke: study protocol for a randomized controlled trial. BMC Neurol 2015;15:87. 
8. Santos MJ, Kanekar N, Aruin AS. The role of anticipatory postural adjustments in compensatory control of posture: 2. Biomechanical analysis. J Electromyogr Kinesiol 2010;20:398-405.

9. Santos MJ, Kanekar N, Aruin AS. The role of anticipatory postural adjustments in compensatory control of posture: 1. Electromyographic analysis. J Electromyogr Kinesiol 2010;20:388-97.

10. Mehravar M, Yadollah-Pour N, Tajali S, Shaterzadeh-Yazdi M-J, Majdinasab NJJoMiM, Biology. The role of anticipatory postural adjustments and compensatory control of posture in balance control of patients with multiple sclerosis. J Mech Med Biol 2015;15:1550087.

11. Salcı Y, Karanfil E, Ayvat E, Balkan AF, Karakaya J, Aksoy S, et al. Investigation of Adaptation to Successive Postural Perturbations in Patients with Multiple Sclerosis. Turk J Neurol 2020;26:24-9.

12. Schinkel-Ivy A, Huntley AH, Aqui A, Mansfield A. Does Perturbation-Based Balance Training Improve Control of Reactive Stepping in Individuals with Chronic Stroke? J Stroke Cerebrovasc Dis 2019;28:935-43.

13. van Duijnhoven HJ, Roelofs J, den Boer JJ, Lem FC, Hofman R, van Bon GE, et al. Perturbation-based balance training to improve step quality in the chronic phase after stroke: a proof-of-concept study. Front Neurol 2018;9:980.

14. Tajali S, Rouhani M, Mehravar M, Negahban H, Sadati E, Oskouei AEJIjoMc. Effects of external perturbations on anticipatory and compensatory postural adjustments in patients with multiple sclerosis and a fall history. Int J MS Care 2018;20:164-72.

15. Massot C, Simoneau-Buessinger E, Agnani O, Donze C, Leteneur S. Anticipatory postural adjustment during gait initiation in multiple sclerosis patients: A systematic review. Gait Posture 2019;73:180-8.

16. Freeman J, Gear M, Pauli A, Cowan P, Finnigan C, Hunter H, et al. The effect of core stability training on balance and mobility in ambulant individuals with multiple sclerosis: a multi-centre series of single case studies. Mult Scler 2010;16:1377-84.

17. De Martino E, Salomoni SE, Winnard A, McCarty K, Lindsay K, Riazati S, et al. Hypogravity reduces trunk admittance and lumbar muscle activation in response to external perturbations. J Appl Psychol 2020;128:1044-55.

18. Nawasreh Z, Logerstedt D, Marmon A, Snyder-Mackler L. Clinical and Biomechanical Efficacies of Mechanical Perturbation Training After Anterior Cruciate Ligament Rupture. J Sport Rehabil 2019;28:877-86.

19. Lurie JD, Zagaria AB, Ellis L, Pidgeon D, Gill-Body KM, Burke C, et al. Surface Perturbation Training to Prevent Falls in Older Adults: A Highly Pragmatic, Randomized Controlled Trial. Phys Ther 2020;100:1153-62.

20. Mansfield A, Wong JS, Bryce J, Knorr S, Patterson KK. Does perturbationbased balance training prevent falls? Systematic review and meta-analysis of preliminary randomized controlled trials. Phys Ther 2015;95:700-9.

21. Cheng Y-S, Chien A, Lai D-M, Lee Y-Y, Cheng C-H, Wang S-F, et al. Perturbation-Based Balance Training in Postoperative Individuals with Degenerative Cervical Myelopathy: A Pilot Study. Front Bioeng Biotechnol 2020;8:108.
22. Aruin AS, Kanekar N, Lee YJ. Anticipatory and compensatory postural adjustments in individuals with multiple sclerosis in response to external perturbations. Neurosci Lett 2015;591:182-6.

23. Kumar C, Pathan N. Effectiveness of manual perturbation exercises in improving balance, function and mobility in stroke patients: a randomized controlled trial. J Nov Physiother 2016;6:2.

24. Khasnis A, Gokula R. Romberg's test. Postgraduate Med 2003;49:169.

25. Widener GL, Allen DD, Gibson-Horn C. Randomized clinical trial of balance-based torso weighting for improving upright mobility in people with multiple sclerosis. Neurorehabil Neural Repair 2009;23:784-91.

26. Schuhfried O, Mittermaier C, Jovanovic T, Pieber K, PaternostroSluga T. Effects of whole-body vibration in patients with multiple sclerosis: a pilot study. Clin Rehabil 2005;19:834-42.

27. Galea MP, Cofré Lizama LE, Butzkueven H, Kilpatrick TJ. Gait and balance deterioration over a 12-month period in multiple sclerosis patients with EDSS scores $\leq 3.0$. NeuroRehabilitation 2017;40:27784.

28. Ilett P, Lythgo N, Martin C, Brock K. Balance and gait in people with multiple sclerosis: a comparison with healthy controls and the immediate change after an intervention based on the Bobath concept. Physiother Res Int 2016;21:91-101.

29. Goh EY, Chua SY, Hong S-J, Ng SS. Reliability and concurrent validity of four square step test scores in subjects with chronic stroke: a pilot study. Arch Phys Med Rehabil 2013;94:1306-11.

30. Wagner JM, Norris RA, Van Dillen LR, Thomas FP, Naismith RT. Four Square Step Test in ambulant persons with multiple sclerosis: validity, reliability, and responsiveness. Int J Rehabil Res 2013;36:253-9.

31. Mitchell KD, Chen H, Silfies SP. Test-Retest Reliability, Validity, and Minimal Detectable Change of the Balance Evaluation Systems Test to Assess Balance in Persons with Multiple Sclerosis. Int J MS Care 2018;20:231-7.

32. Storheim K, Bø K, Pederstad O, Jahnsen R. Intra-tester reproducibility of pressure biofeedback in measurement of transversus abdominis function. Physiother Res Int 2002;7:239-49.

33. van Vliet R, Hoang P, Lord S, Gandevia S, Delbaere KJAopm, rehabilitation. Falls efficacy scale-international: a cross-sectional validation in people with multiple sclerosis. Arch Phys Med Rehabil 2013;94:883-9.

34. Lurie JD, Zagaria AB, Pidgeon DM, Forman JL, Spratt KF. Pilot comparative effectiveness study of surface perturbation treadmill training to prevent falls in older adults. BMC Geriatr 2013;13:49.

35. Bertoni R, Jonsdottir J, Feys P, Lamers I, Cattaneo D. Modified Functional Walking Categories and participation in people with multiple sclerosis. Mult Scler Relat Disord 2018;26:11-8.

36. Morrison S, Rynders C, Sosnoff JJ. Deficits in medio-lateral balance control and the implications for falls in individuals with multiple sclerosis. Gait Posture 2016;49:148-54.

37. Cortesi M, Cattaneo D, Jonsdottir J. Effect of kinesio taping on standing balance in subjects with multiple sclerosis: A pilot study $\backslash \mathrm{m}$ \{1\}. NeuroRehabilitation 2011;28:365-72. 
38. Smania N, Corato E, Tinazzi M, Stanzani C, Fiaschi A, Girardi P, et al. Effect of Balance Training on Postural Instability in Patients With Idiopathic Parkinson's Disease. Neurorehab Neural Repair 2010;24:826-34.

39. Mansfield A, Wong JS, Bryce J, Knorr S, Patterson KK. Does perturbation-based balance training prevent falls? Systematic review and meta-analysis of preliminary randomized controlled trials. Phys Ther 2015;95:700-9.

40. Bhatt T, Yang F, Pai Y-C. Learning to resist gait-slip falls: long-term retention in community-dwelling older adults. Arch Phys Med Rehabil 2012;93:557-64.

41. Rosenblatt NJ MJ, Grabiner MD. Preventing trip-related falls by communitydwelling adults: a prospective study. J Am Geriatr Soc 2013;61:1629-31.

42. Mansfield A, Peters AL, Liu BA, Maki BE. Effect of a perturbationbased balance training program on compensatory stepping and grasping reactions in older adults: a randomized controlled trial. Phys Ther 2010;90:476-91.
43. Protas EJ, Mitchell K, Williams A, Qureshy H, Caroline K, Lai EC. Gait and step training to reduce falls in Parkinson's disease. NeuroRehabilitation 2005;20:183-90.

44. Steib S, Klamroth S, Gaßner H, Pasluosta C, Eskofier B, Winkler J, et al. Perturbation during treadmill training improves dynamic balance and gait in Parkinson's disease: a single-blind randomized controlled pilot trial. Neurorehab Neural Repair 2017;31:758-68.

45. Borghuis J, Hof AL, Lemmink KA. The importance of sensory-motor control in providing core stability. Sports Med 2008;38:893-916.

46. Vera-Garcia FJ, Elvira JL, Brown SH, McGill SM. Effects of abdominal stabilization maneuvers on the control of spine motion and stability against sudden trunk perturbations. J Electromyogr Kinesiol 2007;17:556-67.

47. Mueller J, Hadzic M, Mugele H, Stoll J, Mueller S, Mayer F. Effect of high-intensity perturbations during core-specific sensorimotor exercises on trunk muscle activation. J Biomech 2018;70:212-8. 